Investigator Award from CIHR and A. Zwerling is supported by a CIHR doctoral fellowship award.

Statement of Interest: None declared.

\section{REFERENCES}

1 Joshi R, Reingold AL, Menzies D, et al. Tuberculosis among healthcare workers in low- and middle-income countries: a systematic review. PLoS Med 2006; 3: e494.

2 Pai M, Joshi R, Dogra S, et al. Serial testing of health care workers for tuberculosis using interferon- $\gamma$ assay. Am J Respir Crit Care Med 2006; 174: 349-355.

3 Christopher DJ, Daley P, Armstrong L, et al. Tuberculosis infection among young nursing trainees in South India. PLoS One 2010; 5: e10408.

4 Zwerling A, van den Hof S, Scholten J, et al. Interferon- $\gamma$ release assays for tuberculosis screening of healthcare workers: a systematic review. Thorax 2011; [Epub ahead of print DOI: 10.1136/thx.2010.143180].

5 Pai M, Gokhale K, Joshi R, et al. Mycobacterium tuberculosis infection in health care workers in rural India: comparison of a whole-blood interferon gamma assay with tuberculin skin testing. JAMA 2005; 293: 2746-2755.

6 World Health Organization. TB Data: Data Collected from TB Control Programmes and Estimates Generated by WHO. www. who.int/tb/country/data/download/en/index.html Date last accessed: October 30, 2010. Date last updated: 2010.

7 Mahomed H, Hawkridge T, Verver S, et al. The tuberculin skin test versus QuantiFERON TB Gold $₫$ in predicting tuberculosis disease in an adolescent cohort study in South Africa. PLoS One 2011; 6: e17984.

8 Hill PC, Jackson-Sillah DJ, Fox A, et al. Incidence of tuberculosis and the predictive value of ELISPOT and Mantoux tests in Gambian case contacts. PLoS One 2008; 3: e1379.
9 Bakir M, Millington KA, Soysal A, et al. Prognostic value of a Tcell-based, interferon- $\gamma$ biomarker in children with tuberculosis contact. Ann Intern Med 2008; 149: 777-787.

10 Lienhardt C, Fielding K, Hane AA, et al. Evaluation of the prognostic value of IFN- $\gamma$ release assay and tuberculin skin test in household contacts of infectious tuberculosis cases in Senegal. PLoS One 2010; 5: e10508.

11 del Corral $\mathrm{H}$, Paris SC, Marin ND, et al. IFN $\gamma$ response to Mycobacterium tuberculosis, risk of infection and disease in household contacts of tuberculosis patients in Colombia. PLoS One 2009; 4: e8257.

12 Aichelburg MC, Rieger A, Breitenecker F, et al. Detection and prediction of active tuberculosis disease by a whole-blood interferon- $\gamma$ release assay in HIV-1-infected individuals. Clin Infect Dis 2009; 48: 954-962.

13 Diel R, Loddenkemper R, Niemann S, et al. Negative and positive predictive value of a whole-blood interferon- $\gamma$ release assay for developing active tuberculosis: an update. Am J Respir Crit Care Med 2010; 183: 88-95.

14 Pai M. Spectrum of latent tuberculosis - existing tests cannot resolve the underlying phenotypes. Nat Rev Microbiol 2010; 8: 242.

15 Barry CE, Boshoff HI, Dartois V, et al. The spectrum of latent tuberculosis: rethinking the biology and intervention strategies. Nat Rev Microbiol 2009; 7: 845-855.

16 Mack U, Migliori GB, Sester M, et al. LTBI: latent tuberculosis infection or lasting immune responses to $M$. tuberculosis? A TBNET consensus statement. Eur Respir J 2009; 33: 956-973.

17 Rangaka MX, Wilkinson KA, Glynn JR, et al. Predictive value of interferon $-\gamma$ release assays for incident active tuberculosis: a systematic review and meta-analysis. Lancet Infect Dis 2011; [Epub ahead of print DOI: 10.1016/S1473-3099(11)70210-9].

DOl: $10.1183 / 09031936.00014611$

\title{
Microsatellite alterations at $3 p$ and $19 q$ in EBC DNA of smokers: are they reversible after smoking cessation?
}

\section{To the Editors:}

Carcinogens in cigarette smoke may leave fingerprints in the bronchial tissue in the form of specific mutations that initiate cancer development [1]. Numerous genetic alterations have been recognised as critical effects of cigarette smoke and studied in the airways of current and former smokers. Microsatellite alterations (MAs) at 3p and 19q are among the most studied, being considered useful markers of genetic susceptibility and genome destabilisation in susceptible smokers [2, 3]. Instability and/or loss of heterozygosity at $3 p$ and $19 q$ have largely been reported in the lung tissue, sputum and blood of smokers and lung tumour patients $[2,4]$. These mutations, which are considered an early effect of cigarette smoke, are dose-dependent and related to the number of cigarettes smoked in a lifetime [3]. In addition, short-term exposure to cigarette smoke seems to cause MAs at $3 p$ that are not necessarily a consequence of the development of a neoplastic mass [5].

Our group recently reported MAs at these loci in the exhaled breath condensate $(\mathrm{EBC})$ of smokers and patients affected by nonsmall cell lung cancer, demonstrating that EBC could be a surrogate for tissue in assessing tobacco-induced molecular damage in the lungs [2,3].

Interestingly, although smoking cessation may reverse the clonal expansion of abnormal cells, the persistence of some genetic alterations in former smokers indicates that a high rate of clonal genetic damage persists even after smoking cessation [6].

Several genetic susceptibility markers have been studied after smoking cessation and classified as rapidly reversible, slowly reversible or irreversible [7]. Indeed, to know whether a gene alteration is reversible could turn out to be important, as rapidly reversible genes seem to have different biological functions than slowly reversible or irreversible genes [7].

The aim of this study was to test the reversibility of MAs at $3 p$ and $19 q$ by analysing these markers for the first time in the EBC and whole blood (WB) of smokers at baseline (T0) and then at 12 months after smoking cessation (T1). The correlations between MAs with sex, pack-yrs, exhaled carbon monoxide and Fagerström nicotine dependence score were also investigated. 
The study population consisted of 63 patients (mean \pm SD age $47 \pm 16$ yrs; 41 males) who participated in a multidisciplinary smoking cessation programme with a further genetic study at the Smoking Unit of the Dept of Respiratory Disease, University of Foggia (Foggia, Italy). Furthermore, none of the subjects who underwent the spirometry showed any alterations (forced expiratory volume in $1 \mathrm{~s} 101 \pm 3.3 \%$ predicted; forced vital capacity $102.1 \pm 2.7 \%$ predicted).

Of the 63 smokers in the multidisciplinary smoking cessation programme who provided baseline $\mathrm{WB}$ and $\mathrm{EBC}$ for genetic study, 28 (38\%) subjects (age $53 \pm 8.5$ yrs; 20 males) successfully quit smoking for 12 months and provided new samples. After enrolment, 16 participants received $300 \mathrm{mg} \cdot$ day $^{-1}$ bupropion, six participants received 25-mg Nicorette ${ }_{\circledR}$ Invisi patches (Johnson \& Johnson, Stockholm, Sweden), whereas others opted for a motivational programme.

The EBC was collected using the EcoScreen (Jaeger, Wurzburg, Germany), and the DNA was extracted from both WB and EBC by using a QIAamp DNA Mini Kit (Qiagen, New York, NY, USA).
The analysis of MAs was performed by using the following five polymorphic microsatellite markers from chromosomes $3 \mathrm{p}$ and two from chromosome 19q: 3p24.2 (D3S2338), 3p23 (D3S1266), 3p14.2 (D3S1300), 3p25-26 (D3S1304), 3p21 (D3S1289), 19q13.2 (D19S393) and 19q13.3 (D19S908). Fisher's exact or Chi-squared tests were used to compare qualitative data, and a Wilcoxon test was used for comparison between categories. Data are presented as mean \pm SD. Significance was defined as a p-value of $<0.05$.

A higher success rate for smoking cessation was observed in subjects who provided samples for genotyping, compared with the rate reported in our Smoking Unit for subjects who participated in the usual multidisciplinary smoking cessation programme without genetic studies (38\% versus $20 \%$ ).

As regards the MAs, only 18 patients had informative results in all seven of the loci considered in EBC; regarding the total number of analysed loci, 178 (91\%) out of 196 the analyses resulted in informative microsatellites. Table 1 shows the results of the microsatellite analysis in EBC DNA for each locus and patient.

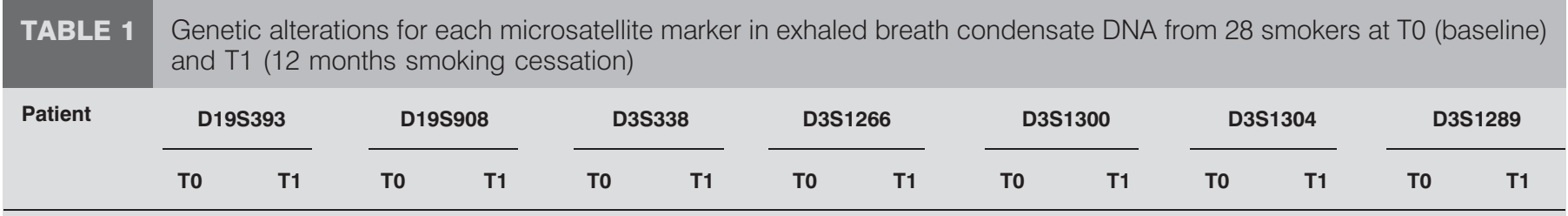

\begin{tabular}{|c|c|c|c|c|c|c|c|c|c|c|c|c|c|c|}
\hline 3 & $\mathrm{LOH}$ & $\mathrm{LOH}$ & $\mathrm{H}$ & $\mathrm{H}$ & $\mathrm{Ml}$ & $\mathrm{Ml}$ & $\mathrm{Ml}$ & $\mathrm{Ml}$ & $\mathrm{LOH}$ & $\mathrm{LOH}$ & $\mathrm{H}$ & $\mathrm{H}$ & $\mathrm{H}$ & $\mathrm{H}$ \\
\hline 5 & $\mathrm{LOH}$ & $\mathrm{LOH}$ & $\mathrm{H}$ & $\mathrm{H}$ & $\mathrm{Ml}$ & $\mathrm{Ml}$ & $\mathrm{Ml}$ & $\mathrm{Ml}$ & $\mathrm{LOH}$ & $\mathrm{LOH}$ & $\mathrm{H}$ & $\mathrm{H}$ & $\mathrm{H}$ & $\mathrm{H}$ \\
\hline 6 & $N$ & $N$ & $\mathrm{H}$ & $\mathrm{H}$ & $\mathrm{H}$ & $\mathrm{H}$ & $\mathrm{LOH}$ & $\mathrm{LOH}$ & $\mathrm{LOH}$ & $\mathrm{LOH}$ & $\mathrm{N}$ & $\mathrm{N}$ & $\mathrm{Ml}$ & $\mathrm{Ml}$ \\
\hline 7 & $\mathrm{Ml}$ & $\mathrm{Ml}$ & $\mathrm{H}$ & $\mathrm{H}$ & $\mathrm{LOH}$ & $\mathrm{LOH}$ & Ml & Ml & $\mathrm{H}$ & $\mathrm{H}$ & $\mathrm{H}$ & $\mathrm{H}$ & MI & $\mathrm{Ml}$ \\
\hline 10 & $\mathrm{Ml}$ & $\mathrm{Ml}$ & $\mathrm{H}$ & $\mathrm{H}$ & $\mathrm{Ml}$ & $\mathrm{Ml}$ & $\mathrm{Ml}$ & $\mathrm{Ml}$ & $\mathrm{H}$ & $\mathrm{H}$ & $\mathrm{LOH}$ & $\mathrm{LOH}$ & $\mathrm{H}$ & $\mathrm{H}$ \\
\hline 11 & $\mathrm{LOH}$ & $\mathrm{LOH}$ & $\mathrm{H}$ & $\mathrm{H}$ & $\mathrm{Ml}$ & $\mathrm{Ml}$ & $\mathrm{H}$ & $\mathrm{H}$ & $\mathrm{H}$ & $\mathrm{H}$ & $\mathrm{H}$ & $\mathrm{H}$ & $N$ & $N$ \\
\hline 12 & $\mathrm{LOH}$ & $\mathrm{LOH}$ & $\mathrm{LOH}$ & $\mathrm{LOH}$ & $\mathrm{Ml}$ & $\mathrm{Ml}$ & $\mathrm{H}$ & $\mathrm{H}$ & $\mathrm{Ml}$ & MI & $\mathrm{H}$ & $\mathrm{H}$ & MI & $\mathrm{Ml}$ \\
\hline 13 & $\mathrm{LOH}$ & $\mathrm{LOH}$ & $\mathrm{LOH}$ & $\mathrm{LOH}$ & $\mathrm{Ml}$ & $\mathrm{Ml}$ & $\mathrm{Ml}$ & $\mathrm{Ml}$ & $\mathrm{H}$ & $\mathrm{H}$ & $\mathrm{H}$ & $\mathrm{H}$ & $N$ & $N$ \\
\hline 14 & $\mathrm{H}$ & $\mathrm{H}$ & $\mathrm{H}$ & $\mathrm{H}$ & $\mathrm{Ml}$ & $\mathrm{Ml}$ & $\mathrm{Ml}$ & $\mathrm{Ml}$ & $\mathrm{LOH}$ & $\mathrm{LOH}$ & $\mathrm{H}$ & $\mathrm{H}$ & $\mathrm{H}$ & $\mathrm{H}$ \\
\hline 19 & $\mathrm{LOH}$ & $\mathrm{LOH}$ & $\mathrm{LOH}$ & $\mathrm{LOH}$ & $\mathrm{Ml}$ & $\mathrm{Ml}$ & $\mathrm{LOH}$ & $\mathrm{LOH}$ & $\mathrm{H}$ & $\mathrm{H}$ & $\mathrm{LOH}$ & $\mathrm{LOH}$ & MI & $\mathrm{Ml}$ \\
\hline 20 & $\mathrm{H}$ & $\mathrm{H}$ & $\mathrm{H}$ & $\mathrm{H}$ & $\mathrm{LOH}$ & $\mathrm{LOH}$ & $\mathrm{H}$ & $\mathrm{H}$ & $\mathrm{H}$ & $\mathrm{H}$ & $\mathrm{H}$ & $\mathrm{H}$ & $N$ & $N$ \\
\hline 21 & $\mathrm{LOH}$ & $\mathrm{LOH}$ & $\mathrm{LOH}$ & $\mathrm{LOH}$ & $\mathrm{LOH}$ & $\mathrm{LOH}$ & $\mathrm{H}$ & $\mathrm{H}$ & $\mathrm{Ml}$ & $\mathrm{Ml}$ & $\mathrm{H}$ & $\mathrm{H}$ & $\mathrm{H}$ & $\mathrm{H}$ \\
\hline 22 & $\mathrm{H}$ & $\mathrm{H}$ & $\mathrm{H}$ & $\mathrm{H}$ & $\mathrm{LOH}$ & $\mathrm{LOH}$ & $\mathrm{LOH}$ & $\mathrm{LOH}$ & $\mathrm{H}$ & $\mathrm{H}$ & $\mathrm{H}$ & $\mathrm{H}$ & $\mathrm{H}$ & $\mathrm{H}$ \\
\hline 23 & $\mathrm{LOH}$ & $\mathrm{LOH}$ & $\mathrm{LOH}$ & $\mathrm{LOH}$ & $\mathrm{LOH}$ & $\mathrm{LOH}$ & $\mathrm{Ml}$ & $\mathrm{Ml}$ & $\mathrm{Ml}$ & $\mathrm{Ml}$ & $\mathrm{H}$ & $\mathrm{H}$ & $\mathrm{H}$ & $\mathrm{H}$ \\
\hline 24 & $\mathrm{LOH}$ & $\mathrm{LOH}$ & $\mathrm{LOH}$ & $\mathrm{LOH}$ & $\mathrm{Ml}$ & $\mathrm{Ml}$ & $\mathrm{Ml}$ & $\mathrm{Ml}$ & $\mathrm{LOH}$ & $\mathrm{LOH}$ & $\mathrm{H}$ & $\mathrm{H}$ & MI & $\mathrm{Ml}$ \\
\hline 25 & $\mathrm{LOH}$ & $\mathrm{LOH}$ & $\mathrm{H}$ & $\mathrm{H}$ & $\mathrm{Ml}$ & $\mathrm{Ml}$ & $\mathrm{Ml}$ & $\mathrm{Ml}$ & $\mathrm{H}$ & $\mathrm{H}$ & $\mathrm{H}$ & $\mathrm{H}$ & $\mathrm{H}$ & $\mathrm{H}$ \\
\hline 26 & $\mathrm{LOH}$ & $\mathrm{LOH}$ & $\mathrm{LOH}$ & $\mathrm{LOH}$ & $\mathrm{Ml}$ & $\mathrm{Ml}$ & $\mathrm{Ml}$ & $\mathrm{Ml}$ & $\mathrm{H}$ & $\mathrm{H}$ & $\mathrm{H}$ & $\mathrm{H}$ & $\mathrm{H}$ & $\mathrm{H}$ \\
\hline 27 & $\mathrm{H}$ & $\mathrm{H}$ & $\mathrm{H}$ & $\mathrm{H}$ & $\mathrm{Ml}$ & $\mathrm{Ml}$ & $\mathrm{H}$ & $\mathrm{H}$ & $\mathrm{LOH}$ & $\mathrm{LOH}$ & $\mathrm{H}$ & $\mathrm{H}$ & $\mathrm{H}$ & $\mathrm{H}$ \\
\hline 28 & $\mathrm{H}$ & $\mathrm{H}$ & $\mathrm{H}$ & $\mathrm{H}$ & $\mathrm{LOH}$ & $\mathrm{LOH}$ & $\mathrm{LOH}$ & $\mathrm{LOH}$ & $\mathrm{H}$ & $\mathrm{H}$ & $\mathrm{LOH}$ & $\mathrm{LOH}$ & $\mathrm{H}$ & $\mathrm{H}$ \\
\hline
\end{tabular}


Loss of heterozygosity ( $\mathrm{LOH}$ ) was found in 48 (27\%) and microsatellite instability (MI) in $43(24 \%)$ out of the 178 informative loci studied. The most frequently altered microsatellites in EBC DNA were D3S338 (in 75\% of the informative DNA samples for that locus), D3S1266 and D19S393 (in 57\% of the informative EBC/DNA samples for those loci). All MAs (LOH and MI) observed at T0 (91 out of 178, 51\%) were unchanged 12 months after quitting smoking (91 out of 178, 51\%) (T1).

When WB DNA was considered, 28 patients had blood samples stored, with 178 (91\%) out of the total 196 loci analysed resulting in informative microsatellites. $\mathrm{LOH}$ was found in $11(6 \%)$ and MI in 15 (8\%) out of the 178 informative loci studied; all MAs ( $\mathrm{LOH}$ and MI) observed at T0 (26 out of 178, 15\%) were unchanged 12 months after quitting smoking (T1).

The number of MAs present in EBC DNA and an increase in tobacco consumption were directly related in the smokers studied. In particular, the frequency of MAs increased from smokers with $<20$ pack-yrs compared with those with $>50$ packs-yrs smoking exposure, with a mean \pm SD number of MAs of $1.6 \pm 1.5$ versus $4.7 \pm 1.3$, respectively $(\mathrm{p}<0.05)$. Further, no correlation between MAs and sex, exhaled carbon monoxide and Fagerström nicotine dependence score were observed.

In this study, we investigated the reversibility of MAs at $3 p$ and $19 \mathrm{q} 12$ months after smoking cessation. Although several markers of genetic susceptibility have already been analysed in relation to smoking cessation and therefore classified as reversible or irreversible genes, to our knowledge, no-one has yet analysed the MAS at $3 p$ and $19 q$, although they are largely recognised as being an important target for cigarette smoke. In accordance with other previous protocols in animals and humans, we analysed MAs at $3 p$ and 19q (ERCC-1, ERCC- 2, fragile histidine triad protein and transforming growth factor- $\beta$ receptor) in DNA from EBC and WB of a group of smokers who participated in a multidisciplinary smoking cessation programme with a genetic study, both at baseline (T0) and 12 months after smoking cessation (T1).

As expected, at baseline, we found high percentages of exhaled MAs at loci studied in smokers; indeed, these values were comparable to those previously reported by our group. Furthermore, we confirmed that MAs at $3 p$ and $19 q$ are dosedependent, as they increased proportionally to the increase in pack-years of cigarette smoking. In agreement with Sozzi et al. [8], our data further suggested that these loci are the most sensitive markers of smoking status.

In accordance with the observations of SIAFAKAS et al. [9] in DNA from sputum cells, we also observed that in the DNA from EBC, MAs are not reduced after short-term smoking cessation. This indicates that MAs at these loci belong to the $21 \%$ of the genes expressed in the airway epithelium of smokers that are irreversible [7]. In agreement with BEANE et al. [7], we believe that, given the rather rapid turnover of airway epithelial cells, the persistence of these changes following smoking cessation may result from a clonal growth advantage to epithelial cells in the airway harbouring these changes.

It will be necessary to follow these subjects and analyse the alterations still present after further time from smoking cessation in order to conclusively demonstrate the irreversibility of
MAs at $3 p$ and $19 q$ and better classify them. Indeed, the correct classification of genetic alterations is very important, as it allows one to recognise their different biological functions. The rapidly reversible genes permit one to distinguish between acute responses to tobacco smoke-induced epithelial cell damage [7], in contrast to those that are slowly reversible for a slower response. However, the irreversible genes are likely to be a useful tool for assessing any past exposure to tobacco smoke; and what is more, these genes provide an insight into why former smokers still run a risk of developing lung cancer [7].

A further result of this study regards the fact that the subjects who were aware of presenting some MAs in their genome, an expression of susceptibility to cancer, stopped smoking with ease, as they were more driven by the fear of developing lung cancer arising from this knowledge than the subjects who stopped smoking when not participating in the genetic studies. As previously demonstrated with other genetic alterations, non-cancer subjects who are informed of their genotype are more likely to quit smoking. Our results are perfectly consistent with the recognised approach to improving smoking cessation that utilises emerging information from molecular genetic studies [10].

In conclusion, we can be said not only to have further confirmed that MAs at $3 p$ and $19 q$ are an early target for cigarette smoke but also to have shown that they are irreversible in the short term after smoking cessation. We believe that it is necessary to follow up on these genetic alterations to determine whether they are still present in ex-smokers after a further period of time from smoking cessation before it can be definitively stated that MAs at $3 p$ and $19 q$ are irreversible and can be employed as markers of past exposure to tobacco smoke.

The further finding of this study, that of a greater percentage of success in smoking cessation among those subjects informed of the presence of MAs in their EBC/DNA and of its susceptibility significance, leads us to support the usefulness of smoking cessation programmes based on genotype information and for its potential ethical consideration.

\section{G.E. Carpagnano*, D. Lacedonia*, G.P. Palladino* and M.P. Foschino Barbaro*}

*Institute of Respiratory Disease, Dept of Medical and Occupational Sciences, University of Foggia, Foggia, and ${ }^{\#}$ Fondazione Salvatore Maugieri, Pavia, Italy.

Correspondence: G.E. Carpagnano, Institute of Respiratory Disease, University of Foggia, Ospedale D'Avanzo, Via degli Aviatori 1, 71100 Foggia, Italy. E-mail: ge.carpagnano @unifg.it

Statement of Interest: None declared.

\section{REFERENCES}

1 Sozzi G, Sard L, De Gregorio L, et al. Association between cigarette smoking and FHIT gene alterations in lung cancer. Cancer Res 1997; 57: 2121-2123.

2 Carpagnano GE, Foschino-Barbaro MP, Spanevello A, et al. 3p microsatellite signature in exhaled breath condensate and tumour 
tissue of lung cancer patients. Am J Respir Crit Care Med 2008; 177: 337-341.

3 Carpagnano GE, Palladino GP, Gramiccioni C, et al. Exhaled ERCC-1 and ERCC-2 microsatellite alterations in NSCLC patients. Lung Cancer 2010; 68: 305-307.

4 Felip E, Rosell R. Testing for excision repair cross-complementing 1 in patients 172 with non-small-cell lung cancer for chemotherapy response. Expert Rev Mol Diagn 2006; 7: 261-268.

5 D'Agostini F, Izzotti A, Balansky R, et al. Early loss of FHIT in the respiratory tract of rodents exposed to environmental cigarette smoke. Cancer Res 2006; 66: 3936-3941.

6 Mao L, Lee JS, Kurie JM, et al. Clonal genetic alterations in the lungs of current and former smokers. J Natl Cancer Inst 1997; 89: 857-862.
7 Beane J, Sebastiani P, Liu G, et al. Reversible and permanent effects of tobacco smoke exposure on airway epithelial gene expression. Genome Biol 2007; 8: R201.

8 Sozzi G, Veronese ML, Negrini M, et al. The FHIT gene 3p14.2 is abnormal in lung cancer. Cell 1996; 85: 17-26.

9 Siafakas NM, Tzortzaki EG, Sourvinos G, et al. Microsatellite DNA instability in COPD. Chest 1999; 116: 47-51.

10 Ito $\mathrm{H}$, Matsuo $\mathrm{K}$, Wakai $\mathrm{K}$, et al. An intervention study of smoking cessation with feedback on genetic cancer susceptibility in Japan. Prev Med 2006; 42: 102-108.

\section{EBUS-TBNA in the differential diagnosis of pulmonary artery sarcoma and thromboembolism}

\section{To the Editors:}

Pulmonary artery sarcoma is a rare tumour of the cardiovascular system. It is often misdiagnosed as acute or chronic pulmonary thromboembolism because its clinical presentation and radiological findings are similar to those of thromboembolism. The diagnosis of pulmonary artery sarcoma by endobronchial ultrasound-guided transbronchial needle aspiration (EBUSTBNA) has not been reported. Herein, we report two cases with mass-like lesion in the pulmonary artery. The lesions were safely approached by EBUS-TBNA, and the tissues obtained by EBUSTBNA were sufficient to diagnose pulmonary artery sarcoma and thromboembolism.

A 79-yr-old female with hypertension and atrial fibrillation presented with sudden-onset left chest and shoulder pain. She had taken warfarin for atrial fibrillation, but the warfarin had been discontinued for 1 week because of a scheduled endoscopy. We performed chest computed tomography (CT), which revealed an extensive intraluminal low-attenuated mass- like lesion involving the entire luminal diameter of the left main and left lower lobar pulmonary artery (fig. 1a). D-dimer was $0.94 \mu \mathrm{g} \cdot \mathrm{mL}^{-1}$ (reference value $<0.4 \mu \mathrm{g} \cdot \mathrm{mL}^{-1}$ ). Positron emission tomography (PET)-CT with ${ }^{18} \mathrm{~F}$-fluorodeoxyglucose (FDG) showed increased FDG uptake, with a maximum standardised uptake value (SUV max) of 18.6 in the left main pulmonary artery (fig. 1c). For a tissue diagnosis, EBUS-TBNA was performed targeting the mass-like lesion encasing the pulmonary artery (fig. 1d). The sonograph revealed a round heterogeneous mass with distinct margin that include some necrotic area. The cytopathological examination confirmed spindle cell malignancy with vimentin and CD31 expression by immunohistochemistry (fig. 1e and f); this was compatible with pulmonary artery sarcoma. She underwent a left pneumonectomy (fig. 1b) and final pathology revealed pulmonary artery sarcoma $4.5 \times 2.0 \times 2.0 \mathrm{~cm}$ in size with marked nuclear pleomorphism and mitotic count of $15 / 10$ high-power fields. 6 months after surgery she is alive without complications or relapse.

A 68-yr-old female with hypertension presented with dyspnoea and syncope. Chest CT revealed a $2.6 \times 3.1 \mathrm{~cm}$ mass-like density in the left main pulmonary artery trunk occupying the entire luminal diameter and extending to the left lower lobe pulmonary artery (fig. 2a). The possibility of pulmonary artery sarcoma was not excluded because the mass-like density in the pulmonary artery was distributed asymmetrically and the left lower lobe pulmonary artery bulged out by the mass. Although the Ddimer level was $11.83 \mu \mathrm{g} \cdot \mathrm{mL}^{-1}$ and only mildly increased FDG uptake (SUV max 3.5) was noted, D-dimer can be elevated in
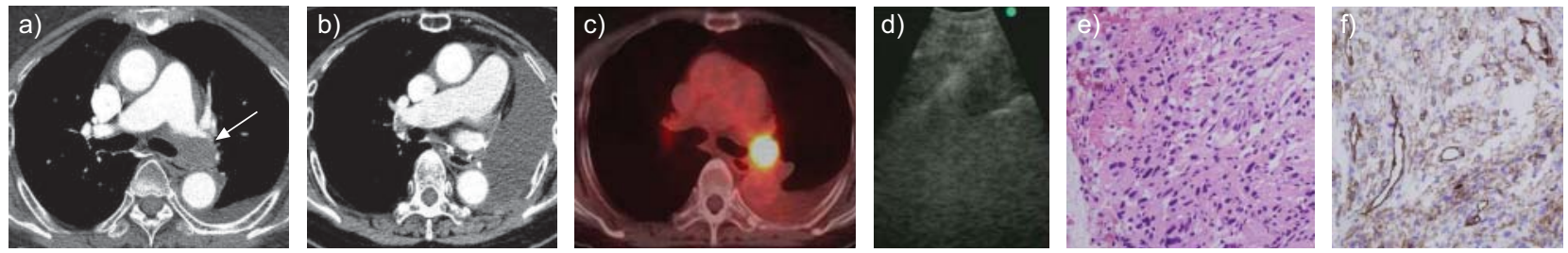

FIGURE 1. Chest computed tomography (CT), positron emission tomography (PET)-CT with ${ }^{18} \mathrm{~F}$-fluorodeoxyglucose (FDG), endobronchial ultrasound-guided transbronchial needle aspiration (EBUS-TBNA) and pathological specimens from EBUS-TBNA in case 1. a) CT scan showing an intraluminal low-attenuation lesion in the left main pulmonary artery. b) The lesion (sarcoma) was resected completely after a left pneumonectomy. c) PET-CT showing increased FDG uptake (maximum standardised uptake value of 18.6) in the intraluminal lesion of the left main pulmonary artery. d) EBUS showing a heterogeneous mass near the left pulmonary artery with the needle inserted in the mass. e) The histological examination revealed poorly differentiated spindle-cell malignancy (haematoxylin and eosin stain $\times 100$ ). f) Tumour cells show focal but definite immunoreacitivity for CD31 (immunostaining $\times 200$ ) 